\title{
Thinking about Ikhtilâf: The Political Construction of Difference in the Islamic Context
}

\section{Mohamed Nachi}

This is an inquiry into the question of difference, of the right to difference in Islamic societies. How is difference treated or engaged there? What are the terms of this debate in Islam? I want to argue that a reflection focusing on the concept of ikhtilâf would be illuminating and enriching in a number of ways. Ikhtilâf is an endogenous concept of wide-ranging and diverse significance, and it engages issues that are at once political, juridical, religious, cultural, ethnic, and social. Moreover, the debates around ikhtilâf were very important during the early period of Islam, while today, contemporary authors, who embrace either a traditional or a modernist perspective, are endeavoring to revisit the concept. I do not wish to put new wine into old skins, however. I mean instead to attend anew to the historical concept of ikhtilâf, to work and rework it in a perspective that seeks to reflect on some of the problems that Islamic societies currently confront. I want to argue that the concept of ikhtilâf provides a needed alternative to sharp oppositions between absolutist readings of Islamic texts and the rejection of any Islamic teaching in the name of either secularism or democracy. There is, within Islamic teaching, a ground for the recognition and political consideration of difference.

In proposing to rethink ikhtilâf, I intend to make explicit the conditions that must occur in order to engage in the political construction of difference, a construction that should be at the basis of the polity and of the state in the Islamic context. Old demons continue to threaten these societies-the intransigent, literalist, and absolutist reading of the sacred texts, the refusal of alterity, the rejection of difference, and the denial of recognition. These must be challenged. Yet, to affirm diversity and difference, to rethink ikhtilâf to that effect constitutes a daunting challenge, for it implies a renunciation of all absolutes. It means confronting issues that have been at the crux of the most heated conflicts plaguing Muslim societies. But that is precisely why ikthilâf should become the ground of the political construction of difference, 
a constitutive element of the polity and of a shared, collective life. As such, ikthilâf can be seen as a promise, as the condition that would enable a new legitimation of the political.

In all societies, social groups and individuals are bound to live together and maintain harmonious relations with each other in spite of their differences and the heterogeneity that separates them. How can they build a common world and peacefully resolve conflicts, tensions, and divergences? This is a process that requires the invention of political and social means of regulation, as well as the establishment of institutions that would legitimate ikhtilâf. Of course, each society must find its own path in order to reach that goal, taking into account its specific heritage and traditions. Yet nothing can be achieved in this direction without a political construction of difference based on the respect of differences and therefore on the acceptance of ikthilâf. Only then will ikhtilâf emerge as a constitutive dimension of the polity, as a condition of shared collective life.

From the outset, it seems important to assert that the perspective adopted here should not be perceived as a way of sowing discord in the community, nor as a denial of the unity of Islam. To the contrary, within ikhtilâf, there is found precisely a way of recognizing diversity in order to preserve unity at the heart of the community. As Ibn 'Arabi said nine centuries ago, "by the unicity of the multitude, we can know the unicity of the Unique."1 In Peter Abelard's terms, this is called unity in diversity, or diversa non adversa. ${ }^{2}$

The reflection I propose on ikhtilaf is therefore inscribed within a problematic that pivots on the following dynamic terms of opposition: unity/ diversity, accord/discord, and conflict/consensus. The main stakes are the recognition of diversity and of difference in and by Islam; the acceptance of divergence, openness to the other, and the striving to develop a spirit of tolerance and of compromise. ${ }^{3}$ Without these goals, one leaves the door open to ostracism, intolerance, and the impoverishment of the self; in a word, to all forms of fundamentalism. In a number of ways, then, the question of ikhtilaf seems to me to be relevant in order to understand both unity and diversity at the heart of the Muslim community and Islam.

Here I will speak about ikhtilâf in general terms, as an integrative principle of Islam, while situating it in its relation to another Islamic principle, namely, ijma (consensus). But I will also allude to the restricted, technical meaning of ikhtilâf, as a form of divergence that is specific to the domain of jurisprudence, or fîqh. I will conclude with some considerations on the broad 
importance of ikhtilâf today and on the uses that can be made of it in order to broach the question of difference-of divergence and diversity-within the Islamic religion. Finally, I will touch on its pertinence for Islam's relation to other religions and other cultures, something which amounts mainly to elaborating a new theoretical and political foundation for sovereignty in Islamic societies.

\section{From the Word to the Concept: The Semantics of Ikhtilâf}

The labor of conceptualization is necessary for any scientific enterprise that claims to energize our ability to be surprised, to go beyond our prejudices and habits of thought. Scientific activity, as Judith Schlanger writes, "is accompanied by a very strong theoretical dependency." ${ }^{4}$ Conceptual elaboration follows a specific mode of reasoning; it obeys rules and procedures that are appropriate for this particular type of intellectual labor. As Gilles Deleuze and Félix Guattari put it: "Concepts are not waiting for us readymade, like heavenly bodies. There is no heaven for concepts. They must be invented, fabricated, or rather created and would be nothing without their creator's signature." 5

In a way, the concept of ikhtilâf remains to be invented, to be created in order for it to be invested with its proper status, that of operator of theoretical representations, of the creative imagination. One must then look for its institutional, social, and political implications. How then to proceed? One must begin with the initial lexical field, the differentiated usages of language, while retrieving and constituting anew the semantic range of the word ikhtilâf, inscribing it within a theoretical perspective capable of turning it into a "new and fecund idea," as Claude Bernard phrased it. ${ }^{6}$ The challenge is to succeed in producing an operative category that makes possible a new intelligibility of the reality it describes and of the imaginary it conveys. And yet, the term ikhtilâf is not univocal, depending on the practices it describes, the fields in which it is deployed (whether religious or juridical or other), or the users who invoke it. The meaning of the word is contingent, as we shall see, on its current and everyday usages. One must therefore be attentive to the subtle differences in usage, in genre, in historical periods and contexts. One must, finally, locate the term in relation to other concepts, whether proximate or competing, as with the concept of ijma .

Etymologically, the word ikhtilâf comes from the root "KH-L-F" (خـد), which means originally "to replace," "to succeed" (يخلف). The same root in- 
forms other terms such as "succession" (خلافة), "contravention," or "infringement" (مخالفة), but also “different,", “to differ," or "vary" (يختلف), all of which bring us back to "ikhtilâf," which carries the meaning of "difference," but also "disagreement," "divergence," "dissension," and "disparity." And it is important to add that, among the varied meanings of the term ikhtilâf, the restricted interpretation, operative within the domain of law ( $f \hat{i} q h)$, is of a "disagreement of opinion," most specifically between the jurists, or füqaha, or between the legal doctrines and schools (madhâhib). Yet the acceptance of this narrower technical sense was overdetermined, since it involved specific interests and privileged benefits, drastically reducing the possibilities of reflecting on other dimensions of ikhtilâf.

\section{Alternative Models: Ijma versus Ikhtilâf}

In the Islamic context, the administration of the polity and the political in general have been largely understood in terms of ijma' (consensus), something that occludes the place of conflict and of difference rather than seeks to acknowledge or accept them. In the framework adopted here, one would have to conceive of the political from the perspective of ikhtilâf so as to be able to grasp the importance of conflict and its place within and between the different sites of power, and to consider the social, juridical and political mechanisms that are necessary for a recognition and an institutionalization of difference. To raise the question of ikhtilaf in such terms is ultimately to interrogate the very structure of the political and within it the place and significance of state sovereignty.

It is true that the model of ijma' ensures a certain overall stability. And yet, it does not provide the means to account for moments of crisis, dysfunction, and discontinuity. Authority and sovereignty are made to appear as monolithic figures endowed with a single unified face. That model also implies abandoning the possibility of a differential sovereignty, which would acknowledge ikhtilâf in order to inscribe it on the body politic and confer legitimacy upon it. Instead, the sites of power present themselves as if they were the expression of a unified (and unitary) polity, as if egalitarian, and moreover, void of divergences and tensions, while knowing full well that these divergences and tensions are real in their manifestations and their consequences. In this regard, ijma is construed as the expression of the will of the community (umma). It presupposes, therefore, a homogenous and unitary vision of both the political community and of sovereignty, which 
would be one and indivisible, while conferring on the state its legitimacy and its mode of existence.

By way of contrast, then, the notion of ikhtilâf allows one to take conflict seriously, to acknowledge the different forms of difference-not only political and social differences, but religious, cultural, ethnic, and linguistic ones as well. For ikhtilaf is constitutive of the polity and is a vital expression of social life. It is the simultaneous manifestation of the divisions of the polity, its contradictions, and internal struggles. ${ }^{7}$ Grasping the multiplicity of voices that are present in the polity and validating the different sites of power, ikhtilâf renders intelligible the conditions of possibility for a peaceful coexistence in spite-and perhaps because-of divergence and conflict. Thus, contrary to ijma', ikhtilâf establishes and institutes conflict and divergence at the heart of the community of believers (umma). Consequently it enables the affirmation of heterogeneity, the plurality of orders of reality, within the political community and within state sovereignty.

And yet Arab-Islamic societies are most often predicated on the idea of ijma'. That is one reason why I seek to posit an alternative-ikhtilâf-in order to think otherwise of the political, in order to posit a different ground for the political construction of difference in the Islamic context. Among the stakes thereby raised is the renewed consideration of the distribution of powers, one that would place ikhtilaff at the structural basis of the political and of sovereignty as well, and by this means acknowledging ikhtilâf as the foundation of legitimacy for different groups in the community.

\section{Ijma : From Customary Practice to Juridical Category}

Ijma is usually presented as a legal category found at the basis of Islamic religious law; as the third source of law, it is most important in legal practice, in the shari $a$. Yet, while not inaccurate, this conception ignores the wider importance of ijma in Arab culture, in pre-Islamic practices and in the developments that followed the birth of Islam during the first century AH. Ijma' was in fact a widespread tribal custom in pre-Islamic Arab society, a "living tradition," according to Joseph Schacht, to which tribal chieftains had recourse in order to ensure approval of their decisions and to determine collective action. ${ }^{8}$ With the advent of Islam, ijma ${ }^{9}$ was no longer practiced in the name of tribal organization, but in the name of the community of the faithful, or the umma. As George F. Hourani explains, "without the Prophet, the early Muslims naturally reverted to a sensible procedure of their an- 
cestors, only changing the source of public authority from the tribe to the religious community or Umma." ${ }^{9}$ The practice of ijma ' was preserved under the auspices of the new religion, but the basis of its authority was radically transformed. I will simply recall here that, with regard to the succession of the Prophet, in the first century AH (seventh century CE) Abû Bakr, the first caliph, was elected on the basis of a certain consensus (ijma'). Over the course of that period, ijma ' was admitted first of all as a practice that had no real legal formulation: "It is probable that neither the Qur'ân nor any genuine Tradition contains such a formulation." ${ }^{10}$

It is only in the second century AH (eighth century $\mathrm{CE}$ ), with the development of the legal theory of $f i \hat{q} h$ (the science of Islamic jurisprudence), that the fûqaha established a legitimate and legal foundation for ïma' as the third source of law. Henceforth, ijma' intervened to resolve juridical questions, but also more broadly, to provide answers to religious questions that were specifically related to belief and to the practice of worship. Subsequently, the füqaha proceeded to claim they were making use of ijma' in order to perpetuate Qur'anic truth, to homogenize practice, and above all to preserve the unity of the community of the faithful, the umma. But how do the fûqaha define ijma'? There are two meanings to recall here. First, and broadly, ijma' is "the unanimous agreement of the umma on a regulation (hukm) imposed by God." Second, and in a more restrictively technical sense, ijma' is "the unanimous doctrine and opinion of the recognized religious authorities at any given time."11

The second, more narrowly legal meaning quickly gained prominence. In establishing ijma' as a juridical source, the fûqaha had needed a legitimate basis to resolve technical problems. This was achieved with the help of a famous hadith (tradition) of the Prophet: "My community does not agree on an error."12 On the basis of this tradition, the theorists of law (usul alfîq) were able to elaborate a legal doctrine that ensured the perdurance of a legitimate basis for ijma .

Muhammad Ibn al-Hasan ash-Shaybâni, disciple of Abû Hanifa in the eighth century $\mathrm{AH}$, and one of the greatest interpreters of Mâlik Ibn Anas (the founding figure of the Maliki school of law), proposed an elaborate formulation for the legitimacy of ijma'. In his edition of the Muwatta' of Mâlik Ibn Anas, ash-Shaybâni asserts that "whatever the Muslims see as good is good with God, and whatever the Muslims see as bad is bad with God" (Mâ ra' âhual-Mu'minûnhasanafahuwa 'indaallâhihasanun, wa mâra' âhual-Muslimûna qabihan fahwa inda allâhi qabîhun). ${ }^{13}$ Thus, it is the Muslims who determine 
what is good and what is evil; they who distinguish truth from falsehoodwhich would mean that they are the ones endowed with the ability required to correctly apprehend what God commands (good) and what He forbids (evil). In this interpretation, neither unanimity nor the consensus of the umma is in question. The subject of the sentence is simply "the Muslims." At this point, in other words, the idea of the umma had yet to be fully appropriated by the fûqaha. But the hadith and its commentators had already opened the way toward the justification of an argument that would prove crucial to the development of a later idea: the idea of the community's consensus (ijma al-Umma) and of its infallibility (isma). In a striking development, the community's inability to fall into error was thus translated into the notion that the community is infallible.

In a real tour de force and with an uncanny skill, of which the fûqaha alone have the secret, the simple notion of a "unanimous agreement" was therefore transformed into a communal consensus branded with the seal of infallibility. As Eric Chaumont remarks, "in the Sunni tradition, the deciding authority, which is in principle granted to the community, was 'confiscated' by the qualified scholars, the mujtahid of the community, in such a way that the ijmâ' umma al-mu'minin (the unanimous agreement of the community of the faithful) is in actuality the 'unanimous agreement of the scholars of the community."'14 As if the fûqaha did not have enough safeguards to preserve the unity of the community! They moreover proclaimed the doctrine of the infallibility of the consensus of the Muslim community.

The doctrine of infallibility did not fail to elicit criticism on the part of some political and religious movements such as the Kharijites and, most notably, the Shiites. Writing in the third century AH (ninth century CE), Sayyâr an-Nazzâm, went so far as to deny the very conceivability of ijma and its evidentiary character. His argument was that "no one can guarantee that a particular community be exempted from error. ${ }^{15}$ But such critiques remained for the most part marginal.

The essential function served by ijma' appeared very early on: to render divergences harmless, even powerless, in the name of the doctrinal integrity of $f \hat{q} q h$ and of the unity of the community. In effect, ijma' functioned as a powerful instrument to crush differences. It became a formidable means in the hands of those who "bind and unbind," the fûqaha, the doctors of the law, who legally, if not legitimately, held on to the power to produce juridical 
norms. Sunni Islam as a whole is now associated with $\ddot{j m} a^{c}$ and is moreover defined by the doctrine of ijma:

It is true, as Ignaz Goldziher maintained, that this great principle "gain[ed] prominence, at least in the past, as a major factor in the adaptive capacities of Islam," that it constituted "an element of conciliation in the disputes provoked by the peculiar development of the schools." ${ }^{16}$ And yet, if ijma was indeed a factor of adaptation at Islam's beginnings, it later became an instrument of Taqlîd, and subsequently an obstacle to change. Taqlîd, it should be noted, refers to a root that means "to imitate, follow, obey." It means "acceptance of, or submission to, authority."

Ijma' has also been erected as a principle that absorbs all differences, under the pretext of the preservation of unity among the community of Muslims, serving, as it were, as a guarantee of respect with regard to the community's integrity. It quickly became the prerogative of a few privileged fûqaha and mutakallimun. Abdelmajid Charfi underscores that "for the majority of usuliyyûn [legal scholars, fûqaha], the only ijma to take into account is that of the doctors of the law, with no regard for the multitude of believers. It will not be surprising therefore that $i j m a^{\prime}$ has in fact consecrated the reproduction of a pattern of thought that is at once elitist, past-oriented, and traditional. It acquired early on a pronounced retrospective character, which prevents it from operating as a factor of change."17

Among the many consequences brought about by ijma' in terms of jurisprudence and religious practices, one is that the spirit of Taqlid became the major component of a static juridico-religious system: hence the subsequent elimination of ijtihâd as well. The supremacy and infallibility of

ijma' as a source of law (hûjja sh (2i) a) did not allow ensuing generations to revise juridical norms, and even less to change them in order to adapt to the changing exigencies of an evolving Muslim society. The call for servile imitation (Taqlid) with regard to decisions and the perpetuation of a closed legal corpus, opaque to change, instituted a model for practice dominantly defined by Taqlid (the sterile imitation of tradition).

\section{Ikhtilâf-a Fundamental Dimension of Islam}

It is a well-attested fact that, from the dawn of Islam, the new Muslim society was taken over by many divergences and dissensions. Ikhtilâf was quickly found at the center of debates and controversies that marked forever the 
formation of classical Islamic thought from its origins onward, and most particularly during the first two centuries of its development. Since that time and until now, the Muslim world has oscillated between two contradictory tendencies. One moves toward the realization of an ideal of unity for the community. The other signals a reality made of differences, divergences, and divisions. In fact, in order to preserve its unity and to remain a seemingly unified community, Islam has had to legitimate certain divergences and integrate within itself a great number of dissensions.

These two tendencies, apparently incompatible, are incarnated in the two integrative principles of Islam I have been discussing: ijma and ikhtilâf. With regard to the latter, however, one more clarification is necessary. Ikhtilâf has often been treated reductively, as if it belonged exclusively to the juridical domain, to the divergence between legal schools and doctrines. In actuality, its reach is much wider. From the moment it appeared, ikhtilâf was mostly the expression of sociocultural differences and of politico-religious rivalries. It was also the manifestation of local particularisms, of regional disparities, and of geographical diversity.

In addition, there is no doubt that ikhtilâf must have an ordinary sense, the use of which is found in everyday life. It should therefore suffice to remain attentive to the flow of everyday life in order to produce an account of the way in which, in discussions and conversations, above all, in arguments and disputes between friends and neighbors, and in public spaces as well (coffee shops, markets), individuals often refer to ikhtilaff. They do so in order to claim the possibility of holding a different opinion, the right to embrace a divergent position, or to advance proper arguments, even contradictory ones. In this way, the recourse to ikhtilâf constitutes a normative support, which allows individuals to justify their differences or divergences, without the constraints of an allegedly shared vision or arguments of uncontested authority. They do not have to surrender to the reason of the strongest. In its ordinary sense, ikhtilâf is used and deployed in a prelegal register and outside of the religious sphere, simply because the differences or divergences at stake are neither juridical nor religious. They may also be familial, social, political or even tied to personal convictions. In a certain manner, this usage, which belongs to the realm of lived experience-daily social existence-is a "secularized" usage, independent of all religious determination. Ikhtilâf thus acquires a positive connotation which valorizes its worldly and ordinary usage, conferring on it a social function of great importance, which 
guarantees mutual respect between members of society and social groups, the acceptance of all kinds of differences, and the recognition of the other in its differences.

The juridical realm is thus only one among the many sites where the divergence of opinions is admitted as legitimate. It is also where ijtihâd, the striving effort at independent interpretation, finds its condition of possibility. The differences, or divergences, of opinion between and among juridical schools and sects (firaq), among intellectual disciplines or spiritual families, were perceived as the expression of "natural" and legitimate manifestations, whence justification could be discovered in the founding texts. A text most often cited in this context is the famous hadith of the Prophet, which says "ikhtil 0 mmatirahmatAllah,"- "The difference of opinion in the community of Mustrms is a favor or a blessing (rahma) on the part of Allah."18

One should not deduce, however, from this favorable perception, according to which differences where legitimately admitted, that it was simply accepted, much less sanctified, without difficulty or hostility. To the contrary, very early on-during the two first centuries-numerous polemics flared up, and debates proliferated on the subject of ikhtilaf and its place, all of which gave birth to a vast heresiographic literature. At the center of this corpus, one finds first of all a particular genre, the Kutub al-maqâlat, or "the books [exposing] the [different] doctrines." Before it became a massive, and in a way representative and characteristic trait of classical Islamic thought, the phenomenon of ikhtilâf thus actively occupied the minds of generations of early Muslims. For the duration of the first two centuries at least, a vast literature took it as its main subject, henceforth elevating it to a true genre.

And yet, according to most Muslim authors, the growth of diverging opinions and the proliferation of different factions and rival schools had to come to a historical conclusion. The state of divergence belongs, in other words, to the ancients, the "Pious Predecessors" (al-Salaf al-sâlih). After them, there would have been no reason to worry any longer about questions of divergence. Ijma had prevailed and brought about a resolution of everything that could have divided the community of Muslims. According to this vision of things, the schools and the sects would now be definitely fixed, their doctrines established, which is why ikhtilâf no longer has any raison d'être. Much as they had done for ijtihâd, then, the fûqaha concluded by the fourth century AH (tenth century CE) that the gate of ikhtilâf was closed as well. 
Ikhtilâf would henceforth be void of legitimacy, and from an acknowledged phenomenon, it became a condemned, even a proscribed one.

This general denial of ikhtilâf endures to this day, which is why reflection upon it has been for the most part suppressed, relegated to the domain of the unthought, even to that of the unthinkable, to invoke Mohammed Arkoun's important term. ${ }^{19}$ This is why it seems to me important to reopen the dossier, to take up anew this reflection on the subject of ikhtilâf.

\section{Ilktilâf: The Other Principle of Islam}

A major consequence of the preeminence of $i j m a^{\circ}$ has been the drastic reduction of the field of ikhtilâf. Worse than that, as the dominant, integrative principle of Islam, ïma has managed to almost annihilate its competitor, its opposite, even. Still, the two principles could probably have coexisted and together preserved both the unity and the diversity of Islam. After all, differences and divergences are unavoidable. Moreover, ijma' and ikhtilâf cannot really be thought separately, but are rather like the two faces of one reality, a duality of forces that, although opposed, are unavoidably complementary.

It is therefore legitimate today to consider the "right of residence" of ikhtilâf as an alternative, integrative principle of differences and divergences, for there are enduring reasons for its existence in contemporary Muslim societies. That is why it must be revived and rethought in light of the current transformations and the new exigencies that these societies confront. And this is most urgently necessary when considering that the classical conception of ijma' has turned out to be insufficient with regard to the resolution of conflict, to tensions and disputes occasioned by the evolution of Muslim societies, as well as to the challenges raised by the socio-political transformations to which I have alluded.

I mentioned earlier that ikhtilâf is in fact an omnipresent phenomenon that accompanied the birth and development of Islam. It played a crucial role in the formation of Islamic thought in the intellectual realm, massively so in the political domain as well. To put it succinctly, one may identify three essential functions that ikhtilâf served:

1. An ideologico-political function: as an instrument in the struggle to satisfy demands related to the respect of difference between social groups, politicoreligious trends, and juridical and theological doctrines.

2. A socioreligious function: as an integrative principle aiming to maintain the unity of Islam while accepting a certain diversity and ensuring the respect of 
divergence, a respect that is inscribed within the limits of the community's unity. Here, ikhtilaff constitutes one of the main means of cohesiveness for the umma.

3. A theologico-juridical function: as a fundamental epistemological given, the aim of which is to enable the coexistence, in the exegetical realm, of different interpretations. In the juridical realm, it grounds the different legal judgments (ahkâm) such as they were formulated in the schools (madhâhib) within, what Henri Laoust called, a "normative system of command and of interdiction" commonly called "Islamic law" (fîqh). ${ }^{20}$

In most cases, at any rate, ikhtilâf has been the expression of political and intellectual tensions, cultural differences, and religious divergences. In some respects, one could say that it has demonstrated its efficacy, most visibly in its ability to contain divisions and divergences within the community, to resolve conflicts and contradictions. This integrative function of the concept of ikhtilâf was realized during the Abbasid period, among others. It was inaugurated by the middle of the eighth century AH (fourteenth century CE), when the Abbasid caliphate appealed to non-Arabs (i.e., Persians) and nonMuslims (i.e., Christians), what are called mawâli, to participate in the exercise of power and administration and, more widely, to participate in cultural life and intellectual activities. During this period the Muslim world became a cauldron of cultures where all kinds of differenc 2 existed: cultural, confessional, intellectual. So, de facto, the acceptance ortrntilâf contributed to the legitimation and recognition of differences that, in return, conferred more legitimacy on the principle of ikhtilâf. Ikthilâf is an operative concept that can profitably serve a better understanding of the current situation in the Muslim world. It cannot be relegated to a mere historical remnant, linked to a distant and superseded past that can therefore be dispensed with. On the contrary, one must consider ikhtilâf as a principle to be actualized anew, a category of thought that can be reclaimed and re-appropriated in the perspective of a critical reworking of classical Islamic thought. ${ }^{21}$

Otherwise put, it is possible to rehabilitate the concept of ikhtilâf in order to turn it into a theoretical and practical exigency, which would enable accounting for, and formulating answers to, the problems currently plaguing Islamic societies. A large number of questions related to minorities, pluralism, and democracy, to the rapport between tûrâth (tradition) and hadâtha (modernity), and more, can be better conceived in terms of the legitimacy (or lack thereof) of ikhtilaff. The concept can illuminate the choices and the concrete stakes around the application or implementation of shari $a$ and 
the place of positive law, around the issues of personal status (al-ahwâl alchakhsiya) and the status of women. ${ }^{22} \mathrm{John}$ Kelsay pertinently observes that:

\begin{abstract}
Contemporary Muslim discourse, for example, can often be read as a debate precisely about the delineation between legitimate and illegitimate ikhtilâf. The widely commented on text known as The Neglected Duty (al-Faridhah al-Ghâiba) provides a case in point. Is it or is not obligatory for all Muslims to struggle for the establishment of a state ruled solely by Islamic law? Are those Muslims who attempt to administer a 'mixed regime' of laws based on Islamic and non-Islamic sources apostates? Should Muslims convinced of the duty to establish a state ruled soleby by Islamic law take it upon themselves to punish apostates through assassinations? What are the limits of legitimate disagreement in Muslim political discourse?23
\end{abstract}

\title{
The Appropriation of Ikhtilâf: The Political Construction of Difference
}

In spite of its past marginalization by Muslim jurists, ikhtilâf can become the object of a necessary work of appropriation and reactivation. It should be formulated anew as an operative concept that would enable laying the foundations for a political construction of difference, which could account for the reality of conflict and for effective divergences (ikhtilâf) in the midst of Islamic societies. Ikhtilâf cannot be reduced to juridico-religious quarrels but should rather cover the diverse range of political opinions, and the full scope of cultural, social, and ethnic diversity. In other words, it should enable a true consideration of differences.

In working toward a new appropriation of ikhtilâf, it might be profitable to begin where Jean-Paul Charnay sees its past trifold success: first, as an inexhaustible, and unfathomable subject of research and of controversy; second, as a mode of justification for some branches of legal implementation in relation to Qur'anic principles and norms; and third, as a possibility of choice between actually existing solutions, or those produced under the pressure of necessity. ${ }^{24}$ One must also reconsider here the initial distinction between two categories of ikhtilâf, the internal and the external. The first has to do with divergences within the community of the faithful: Ikthilâf presupposes the coexistence of a plurality of sects, of juridical doctrines and spiritual families, but on the condition that they all share a common religious ground, and refer themselves to the same legal and religious sources in order to legitimate their positions, whether doctrinal, theological, or other. In this 
respect, ijma' has played an important role as the custodian of cohesion and unity in the community, with the aim of guarding against the "straying" of certain "deviant" sects.

"External" ikhtilâf, the second category, has to do with the divergence between Islam and other religions, in particular, the "People of the Book," between Muslim beliefs and other beliefs, and between Muslim thinkers and non-Muslim thinkers. It is well known that the difference between Muslims and non-Muslims, the situation of non-Muslims in Muslim lands, has been legally resolved. From the first century AH (seventh century $\mathrm{CE}$ ) during the first Islamic conquests, a "legal status," was established for the dhimmi or "protected," who enjoyed the protection of the state and the safeguarding of their rights. In exchange for this, "the people of the dhimma" historically had to pay a "tax" (jizya).

The two kinds of ikhtilâf, internal and external, demonstrate that there exist many levels of divergence, although these remain confined to the religious sphere. Otherwise put, the common denominator for these forms of divergence is that they are all based on fundamentally religious premises. If one wishes to propose a new conception of ikhtilâf, however, a conception suited to the exigencies of actual situations in Islamic societies, it seems indispensable to refrain from conceiving of divergences as belonging exclusively to the religious realm. There are political, ethical, or cultural questions today, the significance of which goes well beyond narrowly religious considerations. Today, some divergences have been secularized and must be treated as such, as legal or political, ethnic, or cultural divergences.

As a prominent legal instrument, ijma' once served as the guardian of cohesion for the community of the faithful. But it has now been superseded. There is no longer a juridico-political space where it could properly, and legitimately, operate. Since the abolition of the caliphate by Kemal Atatürk in 1924, and the advent of nation-states as the new political and juridical frame for most Islamic countries, the exercise of ijma' as a source of law has become close to impossible. Moreover, Islamic law as a whole has largely been overtaken by a positive law of Western inspiration or provenance, with the exception of some limited domains, such as personal or family law (alahwall al-chakhsiya).$^{25}$ Chaumont underscores that the practical modalities for establishing ijma' have also evolved considerably: 
With regard to the "unanimous agreement of the community" (ijma'), one must point out that the situation has singularly changed today. The notion of ijma' has generated the idea that symposiums should be regularly organized, gathering the great authorities of Islam, in order for them to pronounce on the law, on such and such point of order. Whereas they were materially impossible in the past, such symposiums are now organized thanks to the advances made in the realm of communication and transportation. In this case, and with the advent of this very recent procedure in the history of Islamic societies, debate, negotiation, and 'compromise' are certainly more present than they ever were in the modalities that permit establishing ijma' ${ }^{26}$

One could produce similar depictions of the relationship between Islam and the "People of the Book," and, more precisely, with regard to the legal status of the dhimma. On this, the Algerian Islamologist Ali Merad offers quite pertinent remarks:

Does the juridical status of the dhimmi ("protected"), such as it was established in the classical doctrine, still make sense today? First, modern constitutions confer the same dignity and the same rights on the whole citizenry, without distinction of race or of religion. Second, the international community cannot remain indifferent to the fate of oppressed minorities (politically and culturally), because of their ethnic or religious belonging. Is it possible moreover to continue demanding the benefit of human rights and international guarantees in favor of Muslim minorities while ignoring the necessity of similar guarantees for non-Muslim minorities in Islamic lands? ${ }^{27}$

It seems clear, at any rate, that the legal status of the dhimmi has also become obsolete as a result of the historical evolution of the minority question in the context of modern pluralism. With this evolution, we have transcended the age of internal ikhtilâf, narrowly confined to the scale of the religious community (umma). We have reached the age of a secular and agonistic ikhtilâf. New stakes demand new solutions; let us heed the judicious argument made by Ali Merad: "We need a new theology, one that takes into account the unity of humankind, without discrimination based on dogmatic norms and on traditional oppositions (such as Muslims/nonMuslims, believers/nonbelievers). We need a new ethics, one that would properly enable a reconciliation with other cultures and civilizations, which though not constructed under the sign of Islam, are no less pregnant with a promise for humankind as a whole." ${ }^{28}$

Such a new ethics would have to be incarnated in a political construction of difference, which presupposes another way of conceiving ikhtilâf. To think 
ikhtilâf otherwise is, in other words, a necessary condition for accounting for the transformations and changes that have affected Islam and Arab-Islamic societies. To think ikhtilâf in the perspective that has been proposed here will perhaps give Islam a chance to insert itself into a pluralist world marked by coexistence and the diversity of beliefs and cultures, where the right to difference (ikhtilâf) is henceforth a fundamental right for all.

\section{Conclusion}

How to conceive of the implementation and realization of the principle of ikhtilâf? It is obviously difficult to offer ready-made solutions. It would be contrary, moreover, to its very constitutive principles. Let us briefly say that ikhtilâf should be considered as a creative process that emerges out of the "social imaginary" - in the sense proposed by Cornelius Castoriadisthat is to say out of the practices, institutions, traditions, and mechanisms (customs, laws) that are proper to Islamic societies. It is the product of a sociohistorical dynamic. ${ }^{29}$

As an integral part of political sovereignty, ikhtilâf is also constitutive of a plural sovereignty, which legitimates the diversity of voices and favors the imagination at the heart of the social and political body. The question of sovereignty in Islam is surely very complex and difficult to elucidate. I can do no more here than to point to a few paths toward a more extensive reflection, more ample considerations. From the outset it is important to consider that the Islamic conception of sovereignty, at least in its classical sense, cannot be described as either religious or temporal because it is both at once. And yet, the two dimensions are distinct, representing, like the Roman god Janus, two faces of the same reality. Simplifying slightly, one could recall the distinction between two senses of sovereignty as they were summarized by Malcolm H. Kerr:

In the first sense sovereignty signifies ultimate authority above the legal and political system itself, an authority that carries its own justification beyond which there is no moral appeal. In this definition sovereignty is the independent authority to establish values, rights and obligations. In the second sense it is recognized authority to interpret and apply values, rights, and obligations that have been created on the higher plane. A constitutional office may be the locus of sovereignty in the second sense, by virtue of being assigned the authority to interpret and apply the constitution. Sovereignty in the first sense belongs to whomever is recognized to have authority over the constitution itself, to create, change, or abolish it. ${ }^{30}$ 
This distinction evokes another, more ancient one, which was formulated most interestingly in the eighth century AH (fourteenth century CE) by Ibn Khaldûn. In his analysis of dynasties of the monarchy and of the caliphate, Ibn Khaldûn introduces the notion of mûlk (kingdom), which refers to temporal sovereignty as an expression of political control within society. According to his interpretation, there are two levels in which "sovereignty" is exercised. The two levels correspond to two different types of mûlk: mûlk tabî $\hat{\imath}$ (natural sovereignty) and mûlksiyâsî (political sovereignty). Here is how our author defines them: "Natural sovereignty means ruling men in accordance with the aims and desires of the ruler. Political sovereignty means ruling men in accordance with the dictates of reason, in order to secure worldly interests and overt harm." ${ }^{31}$

The mûlk siyâsî is also divided in two types: siyâsa 'aqliya (rational) and siyâsa dîniya (religious). Each type of mûlk is endowed with its own finality (telos), its own foundation and its own legitimacy. However, for Ibn Khaldûn, whatever the nature of mûlk-whether natural or political, rational or religious - sovereignty is recognized as being necessary and unavoidable. Summarized succinctly, the Khaldunian conception reveals the plural character of sovereignty and, to my mind, could offer a fertile path for a more extended reflection on the matter. This would be useful at a time when political and religious groups within Islam are offering different justifications in order to confer on sovereignty its foundation and its legitimacy. Thus Shiite and Sunnite political doctrines, for instance, do not subscribe to the same conception of political sovereignty.

These conceptions, moreover, are radically different from the liberal conception of sovereignty, which is predicated on unity and is the expression of an autonomous, individual subject, an (abstract) citizen, the status of whom is formally determined. One also knows that this unity is constructed upon a juridical and political fiction, whether it is the social contract from Thomas Hobbes to John Rawls, or the idea of the general will dear to Jean-Jacques Rousseau. From the perspective of ikhtilâf, one seeks to gather-and not to divide-the different components of the polity or of the community in their differences and divergences. This presupposes a social and political imaginary that is produced by ikhtilâf and not by an alleged consensus erected as the limit-horizon, the formulation of which is, moreover, confiscated by an elite of clerks or jurists. 
Over the course of this essay, I have attempted to develop an argument calling for the rehabilitation and renewal of ikhtilâf as a legitimate principle for contemporary Arab-Islamic societies. I have tried to show that ikhtilâf, as a principle of legitimation of difference in its diverse forms-religious, political, juridical, theological, cultural-could constitute the basis for a social contract and a political pact based on the recognition of differences at the heart of these societies. I hope that with these reflections, and by demonstrating the historic role and importance of the concept of ikhtilaff, I have been able to bring some elements of response to the challenges confronting Islamic societies today, the greatest of which are the recognition, legitimation and institutionalization of differences.

Mohamed Nachi is Professor, Institut des Sciences Humaines et Sociales, Université de Liège, Belgium. A member of the Institute for Advanced Study in 2010-2011, his recent publications include Introduction à la sociologie pragmatique (Introduction to Pragmatic Sociology), (2006) and Actualité du compromise: La construction politique de la difference (The Relevance of Compromise: The Political Construction of Difference), (2011).

\section{Notes}

1. Quoted in Eric Geoffroy, "L'universalisme de l'Islam: Unité et multiplicite," in "Pour un Islam de paix," special issue, ed. Marc de Smedt, Question de 126 (December 2001): 58. Translation mine; all subsequent translations, unless otherwise noted, are my own.

2. Peter Abailard, Sic et Non: A Critical Edition, ed. Blanche B. Boyer and Richard McKeon (1977).

3. See Mohamed Nachi, ed., Les figures du compromis dansles sociétés islamiques, (2011).

4. Judith Schlanger, "La pensée inventive," in Les concepts scientifiques: Invention et pouvoir, ed. Judith Schlanger and Isabelle Stengers (1991), 68.

5. Gilles Deleuze and Félix Guattari, What is Philosophy? trans. Hugh Tomlinson and Graham Burchell (1994), 5.

6. Quoted in Schlanger, "La pensée inventive," 69.

7. See for example, Nicole Leroux, La citédivisée: L'oubli dans la citéd'Athènes, (1997).

8. Joseph Schacht, "Ikhtilâf," in The Encyclopaedia of Islam, 2nd ed. (1971), 3:1088.

9. George F. Hourani, "The Basis of Authority of Consensus in Sunnite Islam," Studia Islamica 21 (1964): 16.

10. Ibid., 17 .

11. Marie Bernand, "Idjmấ," in The Encyclopaedia of Islam, 2nd ed. (1971), 3:1023.

12. El-Bokhâri, L'Authentique tradition musulmane: choix de hadiths, trans. with introduction and notes by G. H. Bousquet (1964). 


\section{Difference in the Islamic Context}

13. Translation by Joseph Schact, Origins of Muhammadan Jurisprudence (1950), 86, quoted in Hourani, "The Basis of Authority of Consensus," 19-20n3.

14. Eric Chaumont, "La notion de 'compromis' en théorie légale musulmane," in L'actualité du compromis: La construction politique de la différence, ed. Mohamed Nachi, (2011), 217.

15. Marie Bernand, "L'Idjma' chez 'Abd al-Jabbâr et l'objection d'an-Nazzâm," Studia Islamica 30 (1969): 37.

16. Ignaz Goldziher, Le dogme et la loi dans l'Islam [dogma and law in Islam] (1920, reprt 2005), 44 and 46.

17. Abdelmajid Charfi, "Ijtihâd et Idjma': Au-delà des malentendus," in L'Islam pluriel au Maghreb, ed. Sophie Ferchiou (1996), 19; included in Abdelmajid Charfi, La pensée islamique: Rupture et fidélité (2008).

18. See El-Bokhâri, L'authentique Tradition musulmane.

19. Mohammed Arkoun, Pour une critique de la raison islamique (1984), 14.

20. Henri Laoust, Les Schismes dans l'islam (1983).

21. Arkoun, Pour une critique de la raison islamique, 65.

22. See Tariq al-Bîshri, al-Shari a al-islamiyya wa al-Qânûn al-wadh’i [Islamic sharía and legal law] (1996).

23. John Kelsay, "Divine Command Ethics in Early Islam: Al-Shafi'i and the Problem of Guidance," The Journal of Religious Ethics 22, no. 1 (1994): 123.

24. Jean-Paul Charnay, "Fonction de l'Ikhtilâf en méthodologie juridique arabe," in L'Ambivalence dans la culture arabe, ed. Jean Paul Charnay (1967), 229-30.

25. See Al-Bîshri, al-Shari a al-islamiyya wa al-Qânûn al-wadh'i [Islamic shari'a and legal law].

26. Eric Chaumont, "La notion de 'compromis' en théorie légale musulmane," 220.

27. Ali Merad, "L'Islam à l'horizon 2000 (XVe siècle de l'hégire)," Revue Tiers Monde 23, no. 92 (Oct.-Dec. 1982): 767.

28. Merad, "L'Islam à l'horizon 2000," 768.

29. Cornelius Castoriadis, L'institution imaginaire dela société [The imaginary institution of society], (1975), 233 and passim.

30. Malcolm H. Kerr, Islamic Reform: The Political and Legal Theories of Muhammad Abduh and Rashid Rida (1966), 4 .

31. Ibn Khaldûn, Muqaddima, chap. 3, sec. 23. For the English translation, I am relying on Franz Rosenthal, Al-Muqaddimah:AnIntroduction to History (1958) 1:386-88, cited in Kerr, Islamic Reform, 30. 